\title{
Acta
}

Haematologica

\section{Light Chain Amyloidosis}

Guest Editors

Morie Gertz, Rochester, MN

Iuliana Vaxman, Rochester, MN

11 figures, 8 in color, and 16 tables, 2020

Karger $\%$ Basel $\cdot$ Freiburg $\cdot$ Hartford $\cdot$ Oxford $\cdot$ Bangkok $\cdot$ Dubai $\cdot$ Kuala Lumpur . 
S. Karger

Medical and Scientific Publishers

Basel $\cdot$ Freiburg $\cdot$ Hartford $\cdot$ Oxford

Bangkok $\cdot$ Dubai $\cdot$ Kuala Lumpur .

Melbourne $\cdot$ Mexico City .

Moscow $\cdot$ New Delhi $\cdot$ Paris .

Shanghai $\cdot$ Tokyo
Disclaimer

The statements, opinions and data contained in this publication are solely those of the individual authors and contributors and not of the publisher and the editor(s). The appearance of advertisements in the journal is not a warranty, endorsement, or approval of the products or services advertised or of their effectiveness, quality or safety. The publisher and the editor(s) disclaim responsibility for any injury to persons or property resulting from any ideas, methods, instructions or products referred to in the content or advertisements.

Drug Dosage

The authors and the publisher have exerted every effort to ensure that drug selection and dosage set forth in this text are in accord with current recommendations and practice at the time of publication. However, in view of ongoing research, changes in government regulations, and the constant flow of information relating to drug therapy and drug reactions, the reader is urged to check the package insert for each drug for any change in indications and dosage and for added warnings and precautions. This is particularly important when the recommended agent is a new and/or infrequently employed drug.
All rights reserved.

No part of this publication may be translated into other languages, reproduced or utilized in any form or by any means, electronic or mechanical, including photocopying, recording microcopying, or by any information storage and retrieval system, without permission in writing from the publisher or in the case of photocopying, direct payment of a specified fee to the Copyright Clearance Center (see 'General Information').

(c) Copyright 2020 by S. Karger AG,

P.O. Box, CH-4009 Basel (Switzerland)

Printed on acid-free and non-aging paper (ISO 9706)

ISBN 978-3-318-06755-2

e-ISBN 978-3-318-06754-5

karger@karger.com

www.karger.com/aha

Karger ${ }^{\prime}=$ 


\section{Contents}

Editorial

301 Worldwide Perspectives of Amyloidosis

Vaxman, I. (Rochester, MN/Petah-Tikva/Tel-Aviv); Gertz, M.A. (Rochester, MN)

Reviews

304 When to Suspect a Diagnosis of Amyloidosis

Vaxman, I. (Rochester, MN/Petah-Tikva/Tel-Aviv); Gertz, M. (Rochester, MN)

312 Confirming the Diagnosis of Amyloidosis

Wisniowski, B.; Wechalekar, A. (London)

322 The Pathology of Amyloidosis in Classification: A Review

Picken, M.M. (Maywood, IL)

335 Supportive Care in AL Amyloidosis

Cibeira, M.T.; Ortiz-Pérez, J.T.; Quintana, L.F.; Fernádez de Larrea, C.; Tovar, N.; Bladé, J. (Barcelona)

343 Cardiac Care of Patients with Cardiac Amyloidosis

Itzhaki Ben Zadok, O.; Kornowski, R. (Petah Tikva/Tel Aviv); Kornowski, R. (Petah Tikva/Tel Aviv)

352 Solid Organ Transplantation in Amyloidosis

Theodorakakou, F.; Fotiou, D.; Dimopoulos, M.A.; Kastritis, E. (Athens)

365 Conventional Therapy for Amyloid Light-Chain Amyloidosis Milani, P.; Palladini, G. (Pavia)

373 Nonchemotherapy Treatment of Immunoglobulin Light Chain Amyloidosis Van Doren, L.; Lentzsch, S. (New York, NY)

381 High-Dose Melphalan and Autologous Peripheral Blood Stem Cell Transplantation in AL Amyloidosis

Sanchorawala, V. (Boston, MA)

388 Prognosis and Staging of AL Amyloidosis

Dittrich, T.; Kimmich, C.; Hegenbart, U.; Schönland, S.O. (Heidelberg)

401 Author Index

402 Subject Index 